\title{
State of the art in the treatment of mandibular fractures caused by fire-
}

\section{arms: case report}

\author{
Estado da arte no tratamento de fraturas mandibulares por armas de fogo: relato de caso \\ Erasmo Freitas de SOUZA JÚNIOR' \\ (iD) ORCID iD 0000-0003-1714-9226 \\ Hécio Henrique Araújo de MORAIS² \\ (iD) ORCID iD 0000-0002-6450-1483 \\ Eudes Euler de Souza LUCENA² \\ (iD) ORCID iD 0000-0003-3119-7822 \\ José Rodolfo Lopes de Paiva CAVALCANTI2 \\ (D) ORCID iD 0000-0002-1554-3249 \\ Fausto Pierdoná GUZEN² \\ (D) ORCID iD 0000-0002-5458-7236 \\ Dayane Pessoa de ARAúJO² \\ (iD) ORCID iD 0000-0002-2366-4024 \\ Jimmy Charles Melo BARBALHO² \\ (iD) ORCID iD 0000-0002-9921-357x
}

\section{ABSTRACT}

Injuries to the face represent a significant risk to the health of the individual, mainly because of its significance, both functional, because it houses sensory organs and part of the respiratory and digestive systems, as well as esthetic. In this scenario, gunshot wounds in this location cause great concern on account of the magnitude of the damage, and the Oral and Maxillofacial Surgery and Traumatology team must act so that the treatment enables the rehabilitation of the patient in the shortest possible time, with a minimum of complications and sequelae. The objective of this study is to report a clinical case of a 19-year-old female patient with a comminuted fracture of the mandible body caused by a firearm projectile, treated immediately with stable internal fixation using the $2.00 \mathrm{~mm}$ plate-screw system for simplification of the fracture and a $2.4 \mathrm{~mm}$ reconstruction locking-plate on the bone gap. Relevant aspects of the surgical technique and tactics are reviewed and long-term follow-up of the patient is presented.

Indexing terms: Firearms. Internal fixation of fractures. Mandible. Therapeutics.

\section{RESUMO}

As lesões em face representam um grande agravo à saúde do indivíduo, principalmente pela sua significância, tanto funcional, por abrigar órgãos sensitivos e parte dos sistemas respiratório e digestório, quanto estético. Neste cenário, ferimentos por arma de fogo neste local, geram grande preocupação pela magnitude de seus danos, devendo a equipe de Cirurgia e Traumatologia Bucomaxilofacial agir para que o tratamento possibilite a reabilitação do paciente no menor tempo possível, com o mínimo de complicações e sequelas. O objetivo desse trabalho é relatar um caso clínico de uma paciente de 19 anos de idade, apresentando uma fratura cominutiva, com perda de substância, em corpo de mandíbula por projétil de arma de fogo, tratada de forma imediata, com fixação interna estável, utilizando o sistema placa-parafuso 2,0 mm para a simplificação da fratura e placa de reconstrução 2,4 mm locking sobre a lacuna óssea. Aspectos relevantes da técnica e tática cirúrgica são revistos e o acompanhamento da paciente em longo prazo é apresentado.

Termos de indexação: Armas de fogo. Fixação interna de fraturas. Mandíbula. Terapêutica.

\section{INTRODUCTION}

Lesions of the maxillofacial complex are one of the most notorious risks to human health, as they are frequently associated with serious morbidities, loss of function, aesthetic impairment and financial resources required for therapy'.

Reported causes of maxillofacial fractures include air and road accidents, assaults, sports injuries, falls, work- related accidents, attacks by animals and injuries from self-harm. They happen to people of all ages, races, sexes and social arrangements. They mostly afflict males and individuals aged between 21 and 30. Nowadays, however, there is a tendency for both sexes to be affected in roughly equal measure 1 .

As for interpersonal violence, there has been a drastic increase in the incidence of lesions caused by firearm projectiles ${ }^{2-5}$, with the mandibular being the facial

\footnotetext{
${ }^{1}$ Universidade do Estado do Rio Grande do Norte, Programa de Pós-Graduação em Saúde e Sociedade.

${ }^{2}$ Universidade do Estado do Rio Grande do Norte, Faculdade de Odontologia. Rua Almino Afonso, 478, Centro, 59610-210, Mossoró, RN, Brasil Correspondência para / Correspondence to: HHA MORAIS. E-mail: <heciomorais@hotmail.com>.

$\boldsymbol{\nabla v}$

Como citar este artigo / How to cite this article

SOUZA JÚNIOR EF, MORAIS HHA, LUCENA EES, CAVALCANTI JRLP, GUZEN FP, ARAÚJO DP. State of the art in the treatment of mandibular fractures caused by firearms: case report. RGO, Rev Gaúch Odontol. 2018;66(1):88-95. http://dx.doi.org/10.1590/1981-863720180001000123387
} 
bone most affected, and principally the mandibular body ${ }^{3}$, somewhat worrying as it is a single bone with a complex role in functional occlusion and facial aesthetics. These fractures are very painful and even more so when chewing, speaking and breathing. When incorrectly treated, it can lead to significant sequelae including facial asymmetry, malocclusion, TMJ disorders, nervous system repercussions and infection ${ }^{1,6-7}$.

According to Hough, "the only rule regarding the science of ballistics is that the bullet follows no rules" 8 . Thus, with regard to this type of injury, various factors that affect the physiopathology and extent of the trauma must be taken into account in each case, such as: caliber, composition, projectile velocity, shooting distance, angle of penetration, trajectory and direction of the transferred energy $y^{3,9-12}$

Treatment may be either immediate or intermediate, modes of treatment that have been the focus of much discussion in the scientific community2,11. It is the responsibility of the oral and maxillofacial surgeon to weigh up, on a clinical, case by case basis, the arguments that either justify or contraindicate each of the treatment options.

Immediate treatment is conspicuous for requiring a minimal amount of debridement with lower morbidity, enabling a swifter return of function, shorter periods of hospitalization, a one-time surgery, absence of local fibrosis (resulting in greater facility with anatomic reduction) and producing a better aesthetic outcome. However, it is contraindicated in the following circumstances: when the patient has serious infection, bone fragmentation with large loss of substance, avulsion of soft tissue (preventing the covering of the wound), swollen areas that make it impossible to treat the fractures, where attention to overall health is more urgent or where grafts are required on a large scale $\mathrm{e}^{2,13}$.

Intermediate treatment, as well as permitting better case planning, is also recommended when taking into consideration the results of the transfer of high energy into soft tissue which, initially, appears to be viable but could become necrotic within a matter of days, which would result in post-operative complications in the case of immediate treatment. However, the need for two separate surgical procedures, the possibility of dislodged fragments, scar retraction (causing aesthetic impairment), local fibrosis causing greater difficulty with anatomic reduction and the possibility of the patient developing a depressive and/or anxious psychosocial profile through having to put up with mutilations and/or facial distortions until the treatment is finished, are relatively important contraindications with this type of approach ${ }^{2,13}$.

In addition to direct, complex traumas, firearm projectile wounds can cause infection at the bullet's entry or exit point as well as the trajectory in between ${ }^{14}$. Contrary to popular belief, the heat produced by the discharge of the propellant and the friction between the bullet and the barrel of the weapon are not sufficient to sterilize the projectile ${ }^{15}$. Since the skin, the barrier to bacteria, is wounded, this location may essentially be considered to be contaminated with pieces of clothing, and bacteria on the skin or in the air ${ }^{14-16}$.

Therefore, open fractures present a high risk of infection ${ }^{16}$, requiring pre-, trans- and post-operative care aimed at preventing infection, maintaining blood volume, copious intraoral and extraoral irrigation, scrubbing and debridement of the wound, exploration and removal of fractured fragments and debris, reduction and fixation of the stumps to establish bone continuity, antibiotic and anti-tetanus prophylaxis, tissue synthesis, maintenance of suction drainage, daily cleaning of the wound, oral hygiene and the establishment of a suitable $\operatorname{diet}^{2,11,13-15,17-18}$.

For lesions caused by firearm projectiles, broadspectrum anti-tetanus and antibiotic prophylactic coverage must be used and cephalosporin should be the pharmacological group of choice ${ }^{15}$.

As for the removal of the projectile, this should be carefully assessed in order not to subject the patient to a real risk of magnifying the damage. Lead toxicity is a rare complication and does not justify the routine removal of the bullet. Removal is only recommended when the projectile is located superficially, causing functional limitation, presenting a risk to the vital structures, a risk of lead toxicity (when for example it is lodged in spaces between the joints, prompting a long-term deterioration of the joints and in the case of brass or copper-coated bullets, close to central or peripheral nerves) ${ }^{11,15}$.

Nowadays, Open Reduction using stable Internal Fixation (ORIF) is considered the treatment of choice as it is more three-dimensionally stable, provides a swift return of function, obviates the need for postoperative maxillomandibular block, reduces postoperative malocclusion, provides a better cost-benefit as it reduces the chances of complications and potential additional surgical intervention that would result in greater morbidity and higher hospital costs, and speeds up the patient's readmission to society ${ }^{1,3,11,16,19-21}$. 
For stable internal fixation, $1.3 \mathrm{~mm}, 1.5 \mathrm{~mm}$ and $2.0 \mathrm{~mm}$ titanium plate-screw systems are used for simple fractures with no loss of substance. For comminuted fractures with loss of substance, $2.4 \mathrm{~mm}$ reconstruction plates are employed. There are currently two plate/screw models in use: the "non-locking" and "locking" systems. In the former, stability is achieved through the compression of the head of the screw inserted into the plate against the bone interface, on each side of the fracture, the disadvantage being the possibility of instability through the loss of primary reduction, since the incidental forces are distributed to the interface between the screw and the bone. Moreover, there may be a disruption to the blood supply as greater involvement of the cortical bone is required, which would produce a tendency towards bone resorption and infection (when incorrectly indicated). In the second case, the screw exerts compressive force on the plate by means of a blocking system which would be most unlikely to come loose, creating a more rigid reconstruction with less distortion of the reduced fragments, since the forces are concentrated at the plate/screw interface. There is better occlusal relationship, fewer obstacles to blood circulation and less need for precision in terms of plate adaptation ${ }^{3,7,15,19}$.

Based on the current knowledge, the aim of this study was to describe and discuss the technical and theoretical aspects of the treatment of mandibular fractures caused by firearm projectiles, and to present a clinical case.

\section{CASE REPORT}

Nineteen-year-old female patient, victim of aggression by firearm, was treated in the hospital trauma unit. During the initial session of treatment, imaging examinations were carried out (left and right lateral oblique, A-P mandibular and Towne's radiographs), completing the diagnosis of an exposed, comminuted fracture with loss of substance, in the area of the left-side mandibular body with the retention of a foreign body consistent with a firearm projectile (Figure 1), lodged in the ipsilateral region.

It was decided to opt for immediate treatment, initially with the following medication: $1 \mathrm{~g}$ Dipyrone (IV) every 6 hours to control pain, $4 \mathrm{mg}$ Dexamethasone (IV) every 8 hours to control swelling, $500 \mathrm{mg}$ Cefazolin (IV) every 6 hours combined with 500 mg Metronidazole (IV) every 8 hours to prevent generalized infection, $0.5 \mathrm{~mL}$ Anti-tetanus Vaccine (IM) and 5,000 UI Anti-tetanus Drip (IM) to prevent tetanus and $40 \mathrm{mg}$ omeprazole (IV) a day, to protect the gastric mucosa.

Copious rinsing with a saline solution and conservative intraoral and extraoral debridement of the wound were carried out. Through a large submandibular access (Figure 2), the projectile fragments were removed (and subsequently sent for forensic examination) along with any nonviable hard tissue (Figure $3 a$ ), and the tips

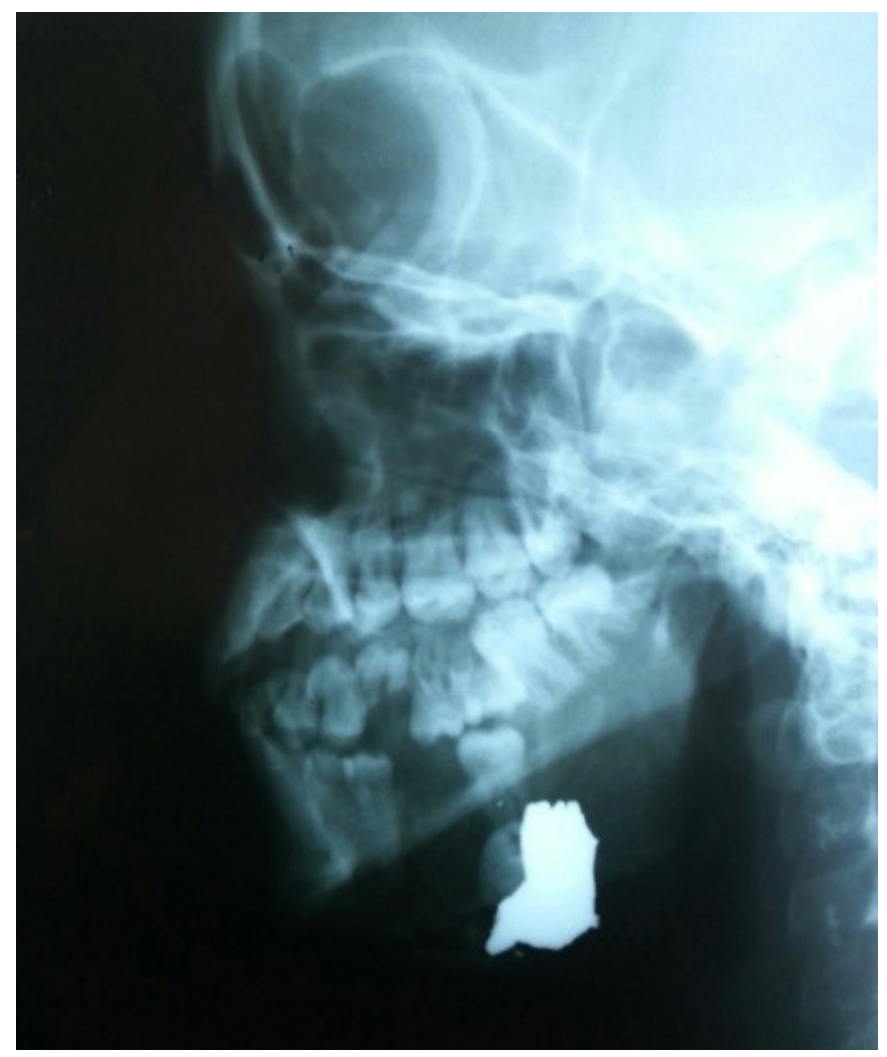

Figure 1. Lateral oblique radiograph evidencing comminuted fracture of the mandibular body with displaced teeth and retention of foreign body consistent with firearm projectile

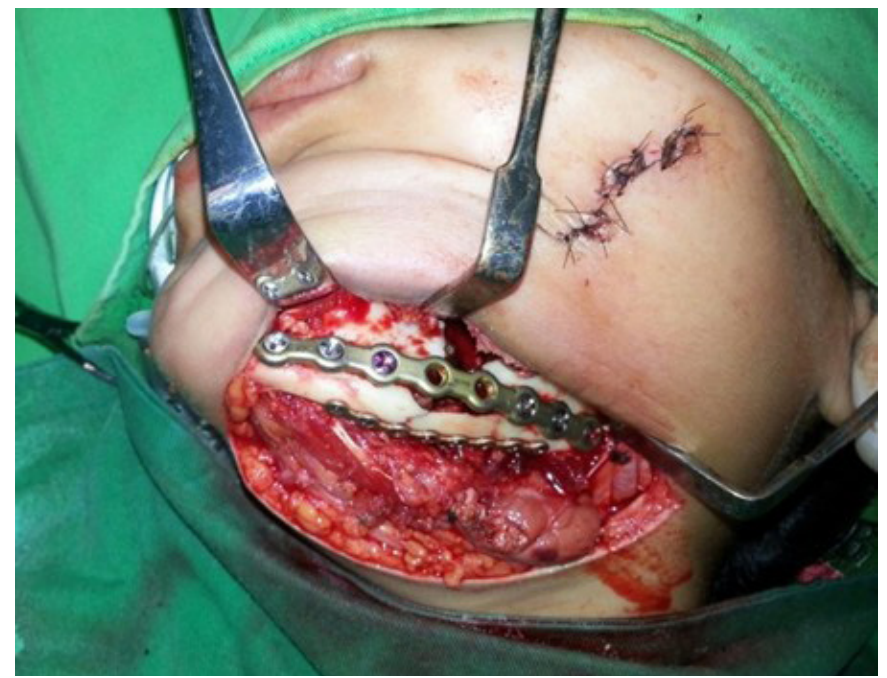

Figure 2. Submandibular access with reduction of fracture using $2 \mathrm{~mm}$ screw and plate system in the basilar region for simplification of the fracture and 2.4 $\mathrm{mm}$ reconstruction Locking-plate for final stabilization. 
of the fractured stumps were regularized using a lowspeed drill. The trans-operative maxillo-mandibular block was then performed using a steel wire, followed by the simplification of the fracture using the $2 \mathrm{~mm}$ screw and plate system in the basilar region (Figure 2), performing the said reconstruction with the fixation of a $2.4 \mathrm{~mm}$ lockingplate on the fracture (Fig. 2), the surgery terminating with the suturing of all the planes (Figure $3 \mathrm{~b}$ ).

The $3.2 \mathrm{~mm}$ suction drain was kept in place for 48 hours, a nasogastric probe was inserted and there was a postoperative prescription of cephalexin antibiotic for 7 days, by mouth, once the patient is discharged. Rehabilitative physical therapy was initiated while the patient was still in her hospital bed.

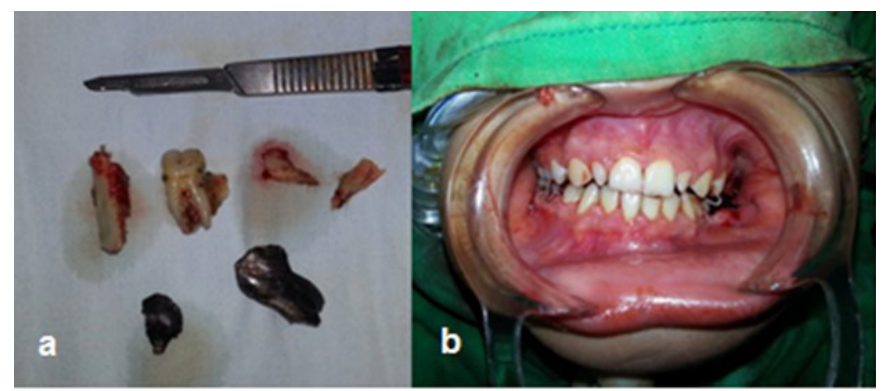

Figure 3. a) Removed fragments of projectile and nonviable hard tissue; b) Intraora appearance after suturing of the wounds.

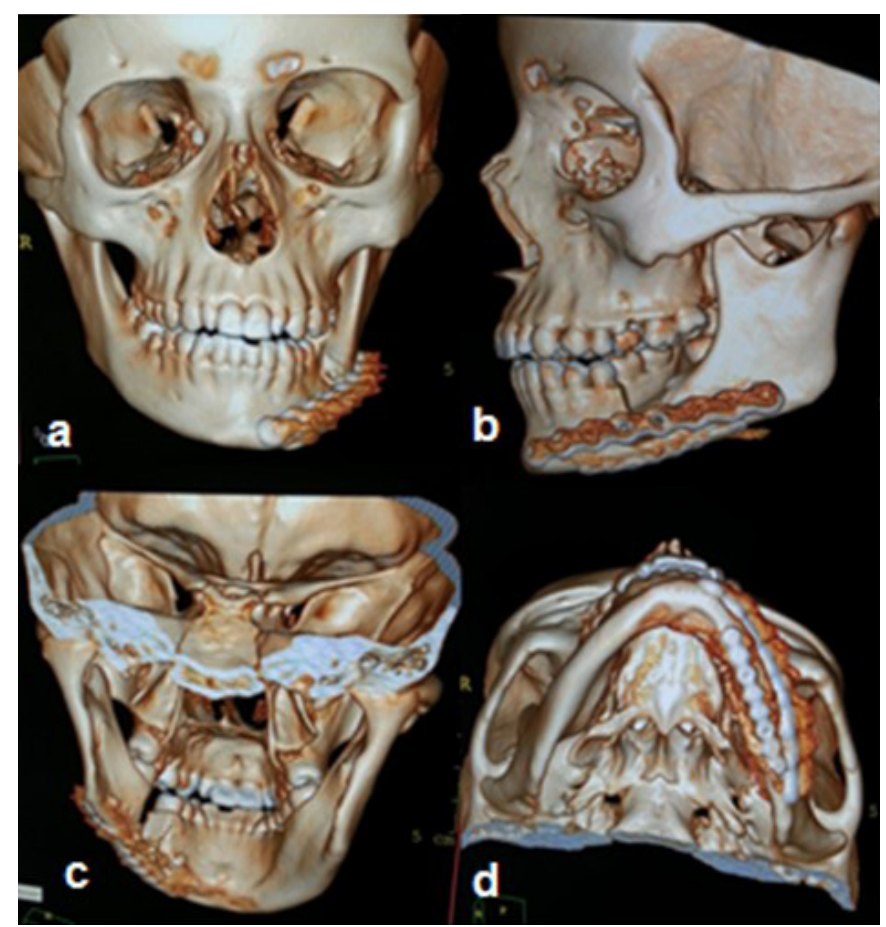

Figure 4. Tomography examination. Note the correct installation of plates/screws and basilar alignment. a) Front view; b) Lateral view; c) View of inside the mandible; d) Axial view of the mandible.

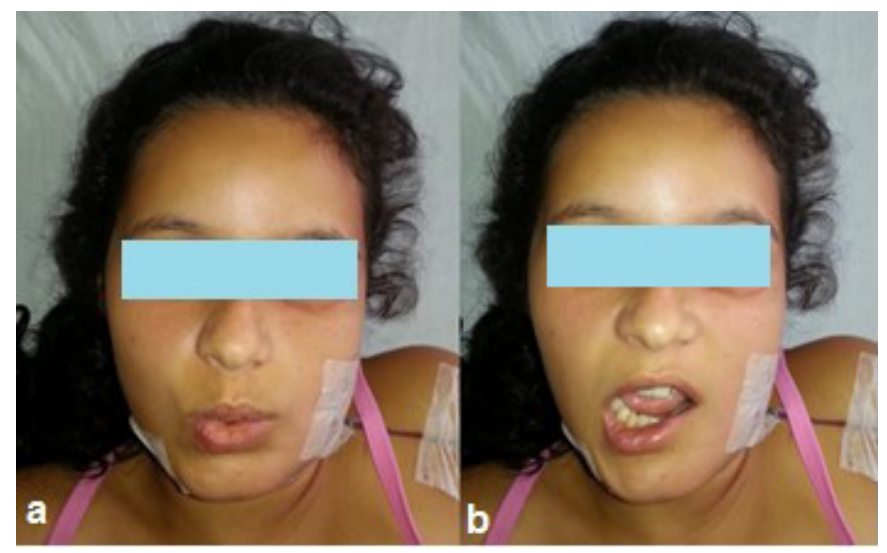

Figure 5. Left-side hypomobility of lower lip observed (temporary). a) a Whistling motion; b) Smiling motion.

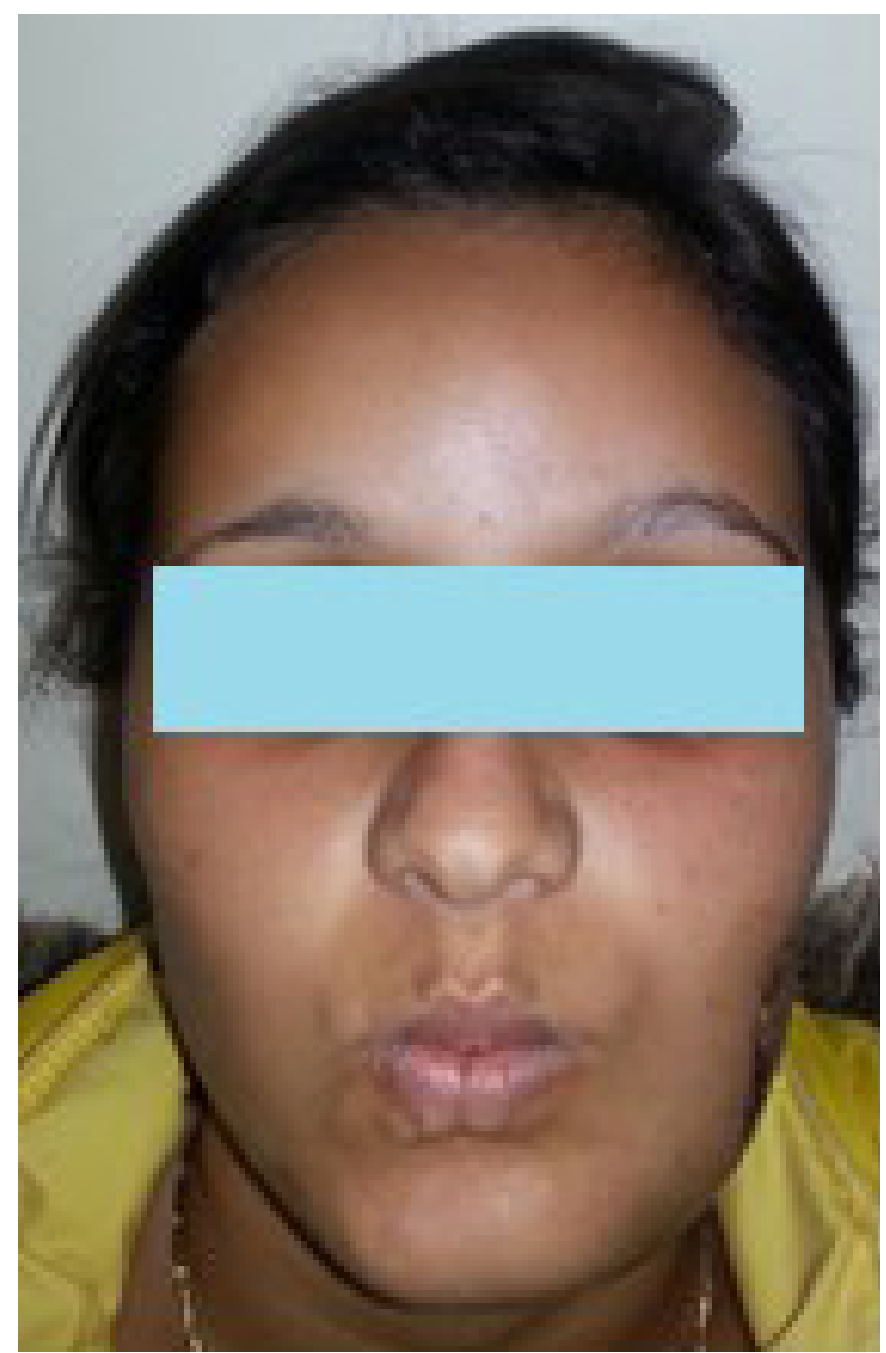

Figure 6. Through the whistling movement, the disappearance of neuropraxia in late post-op can be noted.

A Computed Tomography (CT) imaging examination revealed the correct installation of the plates and screws and a perfect alignment of the basilar region 
(Figure 4). The patient presented with hypomobility of the left-side lower lip in immediate post-op (Figure 5), developing with no impairment of the facial nerve in late post-op (Figure 6), with good healing and occlusion (Figure 7), as well as satisfactory facial aesthetics (Figure 8), and was discharged after 3 days, with subsequent follow-up for 20 months.

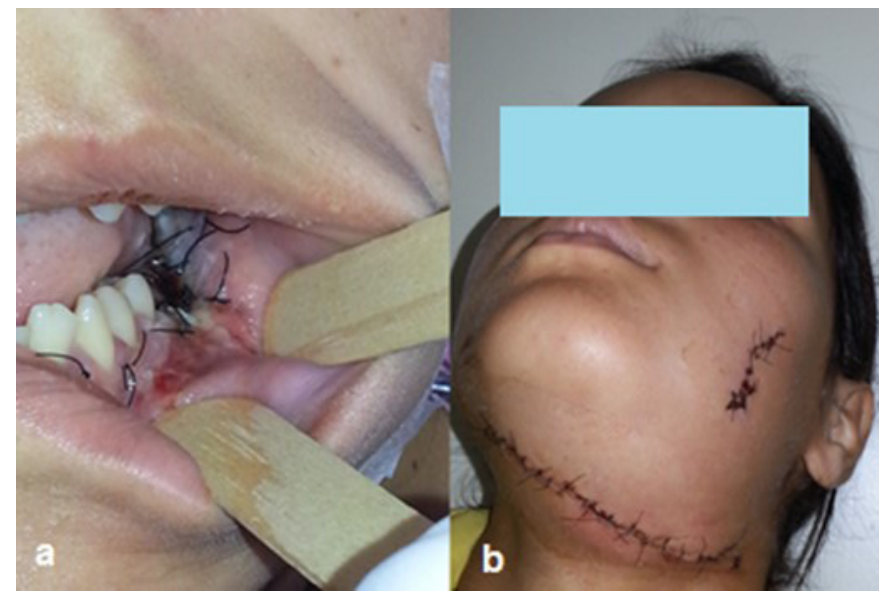

Figure 7. a) Intraoral appearance after 7 days; b) View of submandibular access after 7 days.

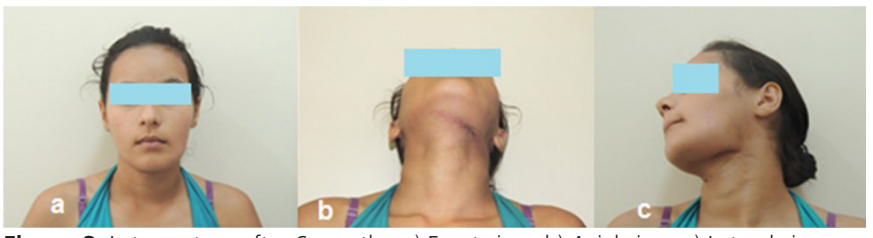

Figure 8. Late post-op after 6 months. a) Front view; b) Axial view; c) Lateral view.

\section{DISCUSSION}

Firearm projectile lesions are a significant problem for public health, characterized by significant morbimortality and cost to society ${ }^{18,22}$. The present case possesses characteristics consistent with retrospective studies of facial fractures $2,6-7,12,22-25$ that point to the mandible being the bone most impacted, with the mandibular body being the portion most affected, predominantly involving individuals in their 20s, 30 s and 40s.

As far as treatment is concerned, the option for the immobilization, reduction and internal fixation of the stumps, initially, is because of the link to reduced rates of complications. Thus, the course of the healing process is not interrupted by a subsequent surgery (on the same wound) also reducing anxiety and stress associated with patients with facial traumas and/or non-functional mandibles ${ }^{2,13,16}$.

Minimal rates of complications were observed in the study by Motamedi who performed a 19year retrospective study with the aim of evaluating hospitalized patients treated for firearm injury to the facial skeleton. In the final survey of 51 patients, 30 had primary repair with open reduction and 21 had intermediate treatment, as they presented with clinical conditions that made it impossible to undergo immediate therapy. As a result, it was found that, in the group undergoing primary treatment, only 6 patients presented with a minor complication, such as the presence of scars. With the choice of intermediate treatment, as in this case, fibroses could appear around the bone segments which would make location and fixation difficult.

As for the benefits of antibiotic prophylaxis, the literature has demonstrated that the administration of a suitable antibiotic regimen significantly reduces the number of post-operative infections in soft and hard tissue with open treatment of mandibular fractures ${ }^{2,15,26}$. This need was proved in the studies of Zallen \& Curry ${ }^{27}$, in which 62 patients were treated for fractures involving dentoalveolar segments. Thirty-two patients received antimicrobial therapy. The remaining 30 patients did not. As a result, $50.33 \%$ of those patients who did not receive antibiotics had infectious complications while, of those subjected to antibiotic therapy, only $6.25 \%$ exhibited any manifestation of this kind.

In the present case, bearing in mind that it was an open fracture with both intraoral and extraoral involvement, the option to use pre-operative prophylaxis with cefazolin, which is a first-generation cephalosporin, was justified by the fact that it is very effective against Staphylococcus aureus, producer of penicillinase and the largest pathogen of the skin and mucosa, and also therefore the biggest colonizer of open wounds. Metronidazole was also prescribed due to its significant anaerobicidal activity ${ }^{28-29}$.

As for the submandibular approach, additional care should be taken with the incision, through the presence of the facial neurovascular bundle. However the presence of these anatomic structures does not dispense with the indication for this access in the approach to the mandibular body, as seen in the studies by Scolozzi \& Richter ${ }^{21}$ who performed a retrospective 
evaluation of the use of $2.4 \mathrm{~mm}$ reconstruction plates for mandibular fractures, in which 65 patients were subjected to this procedure. An extraoral approach was used on 41 patients (63.1\%), particularly for body and angle fractures, and no patients reported dissatisfaction with the scar or suffered permanent paralysis of the facial nerve.

The benefits of stable ORIF can be seen in studies such as that of Ellis, Muniz \& Anand ${ }^{24}$ in which, over a period of 10 years, the treatment methods used were evaluated along with the results for patients with mandibular fractures, arriving at a total of 196 patients, with 198 comminuted fractures, for which open reduction with stable internal fixation was used in the majority of cases (74\%). In these cases, lower complication rates were observed than with the other treatment modes (external pin fixation and closed treatment with maxillomandibular block).

The aim of the study conducted by Rana et al. ${ }^{18}$ was to determine the final outcome of treatment with open reduction internal fixation versus closed reduction and maxillomandibular block, in the treatment of firearm wounds to the mandible. Sixty patients with firearm wounds were randomly distributed into two groups, $A$ and $B$, with 30 patients per group. Group A was treated with open reduction internal fixation and Group B with closed reduction and maxillomandibular block. The patients were discharged and subsequently monitored for a period of three months, with complications being evaluated every 15 days. It was concluded that the patients treated with open reduction tended to have fewer complications than those with closed reduction and that open reduction is the better treatment option for dealing with mandibular firearm injuries.

In the present case, stable internal fixation was performed at two different points in time, firstly with the simplification of the fracture using the $2 \mathrm{~mm}$ screw/plate system, the aim of which is to join smaller fragments capable of repair, in order to minimize the damage and provide greater bone support and anatomic parameter for the final reconstruction5. Stable internal fixation was then used in the actual reconstruction with a $2.4 \mathrm{~mm}$ locking-plate on the continuous defect.

The use of the $2.4 \mathrm{~mm}$ locking system is quite widely cited in the literature for the type of fracture reported (comminuted, with loss of substance). It may be used to fill a gap or comminuted areas, providing better stabilization of the proximal and distal segments by way of a passive adjustment between the plate and the bone, without impairing vascular supply, enabling adequate healing and, in addition, it does not require large inclinations of the plate to fit in the bone, thereby reducing surgery time, and this minimizes complications and sequelae, such as infections and bad joins $3,12,19$.

Peleg \& Sawatari12 conducted retrospective evaluation on the management of gunshot wounds to the mandible over a period of 10 years, on a sample of 92 patients. All of those who presented with continuity defects were subjected to the use of reconstruction plates. There was a link between this form of treatment and a lower rate of complications.

Similarly, Scolozzi \& Richter ${ }^{21}$ conducted a retrospective evaluation of the use of $2.4 \mathrm{~mm}$ reconstruction plates for mandibular fractures. As a result, it was found that 65 patients were subjected to the fitting of $2.4 \mathrm{~mm}$ reconstruction plates. They concluded that reconstruction plates can be used to treat serious mandibular fractures with a low rate of complications and high success rate, being indicated in cases where the bone can no longer support compressive forces (comminuted fractures, serious fractures, fractures with displacement, infected fractures and atrophic mandibular fractures).

Maliska, Lima Júnior \& $\mathrm{Gi}^{23}$ also found that comminuted fractures and fractures involving substantial loss of bone received good treatment with the use of reconstruction plates.

Munante-Cardenas, Nunes \& Passeri ${ }^{30}$ evaluated the records of 119 patients treated for mandibular fractures, between January 2006 and December 2011. They found that comminuted fractures and large-scale displacements were well treated through open reduction with extraoral access, using the $2.4 \mathrm{~mm}$ system of plates.

Despite the low level of post-op complications with the use of reconstruction plates, mainly when using the locking system, they can still occur, it being necessary to take certain precautions, such as copious rinsing with a saline solution and debridement with the removal of fractured fragments that are not viable for reconstruction. In the case reported here, teeth 36 and 37 involved in the fracture line were removed (suggesting subsequent rehabilitation using a graft 
and implant). The stumps were regularized with the removal of the spicules of bone.

These findings were evidenced in the study by Kirkpatrick, Gandhi \& Sickels ${ }^{7}$ who examined the incidence in patients treated with the locking system through a retrospective 28-month study carried out by independent examiners. A total of 56 plates were used for the 42 patients. The rate of infection after surgery was minimal. Eight patients presented with pre-operative infections while just 3 continued to experience infection after the surgery. With the exception of one patient, all those with infections, in post-op only, were smokers. The other patient who was not previously infected, was treated for an angular fracture in which a tooth was left on the fracture line at the time of the initial surgery. Nevertheless, all the post-op infections were resolved using local measures without loss of fixation. The pre-op history of infection, tobacco usage and maintenance of teeth on the fracture line were important factors in the etiology of the post-op infection.

In the post-operative phase, rehabilitative physical therapy using manual massage was prescribed in order to increase the supply of blood and eliminate metabolic debris ${ }^{13}$. Post-op antibiotic therapy was carried out (at home) using cephalexin, for the same motives as the use of cefazolin, as mentioned earlier.

The need to take this medication after surgery can be seen in the studies of Miles, Potter \& Ellis ${ }^{26}$ whose aim was to determine the post-op need for and/ or efficacy of antibiotics in the treatment of mandibular fractures, by way of a randomized, prospective study comprising patients who came in for surgical treatment of (open) mandibular fractures, subsequently subjected to open reduction internal fixation. The patients were

\section{REFERENCES}

1. Ghodke MH, Bhoyar SC, Shah SV. Prevalence of mandibular fractures reported at C.S.M.S.S Dental College, Aurangabad from February 2008 to September 2009. J Int Soc Prev Community Dent. 2013;3(2):51-8. doi: 10.4103/2231-0762.122428

2. Motamedi MHK. Management of firearm injuries to the facial skeleton: Outcomes from early primary intervention. J Emergencies, Trauma Shock. 2011;4(2):212-6. doi: 10.4103/0974-2700.82208

3. Pereira C, Santos PL, Jardim E, Garcia Júnior IR, Shinohara $\mathrm{E}$, Araujo M. The Use of 2.4-mm Locking Plate System in Treating Comminuted Mandibular Fracture by Firearm. randomly divided into two groups: those who received antibiotics in the post-operative period and those who did not ( $A b$ and non-Ab, respectively). A total of 181 patients met the inclusion criteria. The group with antibiotics numbered 81 while there were 100 individuals in the group that did not use antibiotics. Twenty-two patients showed evidence of infection in the 8 -week follow-up period. There were 8 infections in group $A b$ and 14 in the non-Ab group.

\section{CONCLUSION}

The complexity of the physiopathology of injuries from firearm projectiles demands that the Oral and Maxillofacial surgeon understands the treatment needs with pre-operative care being indispensable, for example: proper medication, copious rinsing and debridement of the wound. Immediate treatment and stable internal fixation are indicated whenever possible in these cases. The use of reconstruction plates using the "locking system" for comminuted fractures and/ or loss of substance is advocated as well as post-op antibiotic therapy.

The use of these measures creates a tendency toward successful treatment, with few or no complications and sequelae.

\section{Collaborators}

EF SOUZA JUNIOR and HHA MORAIS were responsible for the conduct of the case. EES LUCENA, JRLP CAVALCANTI, FP GUZEN and DP ARAÚJO were responsible for writing and reviewing the article. JCM BARBALHO was responsible for the bibliographic review.

Craniomaxillofacial Trauma Reconstr. 2012;5(2):91-6. doi: 10.1055/s-0032-1313364

4. Prado R, Salim MAA. Cirurgia Bucomaxilofacial: diagnóstico e tratamento. Rio de Janeiro: Guanabara Koogan; 2004.

5. Alpert B, Tiwana PS, Kushner GM. Management of Comminuted Fractures of the Mandible. Oral Maxillofac Surg Clin North Am. 2009;21(2):185-92. doi: 10.1016/j.coms.2008.12.002

6. Czerwinski M, Parker WL, Chehade A, Williams HB. Identification of mandibular fracture epidemiology in Canada: Enhancing injury prevention and patient evaluation. Can J Plast Surg. 2008; 16(1):36-40.

7. Kirkpatrick D, Gandhi R, Van Sickels JE. Infections associated with locking reconstruction plates: a retrospective review. 
J Oral Maxillofac Surg. 2003;61(4):462-6. doi: 10.1053/ joms.2003.50089

8. Hough RH. Gunshot wounds to the head and neck. In: Kelly JPW, editor. Oral and maxillofacial surgery. Knowledge update. Chicago, IL: American Association of Oral and Maxillofacial Surgeons; 1995. p. 65-68.

9. Inchingolo $F$, Tatullo $M$, Marrelli $M$, Inchingolo $A D$, Pinto $G$, Inchingolo AM, et al. Short report of an unusual ballistic trauma. Int J Surg Case Rep. 2011;2(8):272-4. doi: 10.1016/j. ijscr.2011.08.009

10. Sansare K, Khanna $V$, Karjodkar F. The role of maxillofacial radiologists in gunshot injuries: A hypothesized missile trajectory in two case reports. Dentomaxillofacial Radiol. 2011;40(1):53-9. doi: $10.1259 / \mathrm{dmfr} / 72527764$

11. Morais HHA, Carvalho RWF, Rocha NS, Vasconcelos $B C E$, Vasconcellos RJH. Tratamento imediato de fratura de mandíbula por projétil de arma de fogo. RGO, Rev Gaúch Odontol. 2010;58(3):399-403.

12. Peleg M, Sawatari Y. Management of gunshot wounds to the mandible. J Craniofac Surg. 2010;21(4):1252-6. doi: 10.1097/ SCS.0b013e3181e2065b

13. Motamedi MHK. Comprehensive Management of Maxillofacial Projectile Injuries at the First Operation; "picking up the Pieces." Trauma Mon. 2012;17(4):365-6. doi: 10.5812/traumamon.9279

14. Von See C, Rana M, Stoetzer M, Wilker C, Rücker M, Gellrich $\mathrm{N}-\mathrm{C}$. A new model for the characterization of infection risk in gunshot injuries:Technology, principal consideration and clinical implementation. Head Face Med. BioMed Central Ltd; 2011;7(1):18. doi: 10.1186/1746-160X-7-18

15. Miloro M. Princípios de cirurgia bucomaxilofacial de Peterson. São Paulo: Santos; 2011.

16. Luz JGDC, Moraes RB, D'Ávila RP, Yamamoto MK. Factors contributing to the surgical retreatment of mandibular fractures. Braz Oral Res. 2013;27(3):258-65. doi: 10.1590/S180683242013005000007

17. Gazal G. Evaluation of the effectiveness of early or delayed treatment upon healing of mandibular fractures: a retrospective study. Eur J Dent. 2015;9(1):87. doi: 10.4103/13057456.149650

18. Rana M, Warraich R, Rashad A, Von See C, Channar KA, Rana $M$, et al. Management of comminuted but continuous mandible defects after gunshot injuries. J Care Injured. 2014;45(1):20611. doi: 10.1016/j.injury.2012.09.021

19. Lee K, Yoon K, Park K. Treatment of extensive comminuted mandibular fracture between both mandibular angles with bilateral condylar fractures using a reconstruction plate: a case. J Korean Assoc Oral Maxillofac Surg. 2014;40(3):135-139. doi: 10.5125/jkaoms.2014.40.3.135

20. Gabrielli MAC, Gabrielli MFR, Marcantonio E, Hochuli-Vieira E. Fixation of mandibular fractures with $2.0-\mathrm{mm}$ miniplates: Review of 191 cases. J Oral Maxillofac Surg. 2003;61(4):430-6. doi: 10.1053/joms.2003.50083

21. Scolozzi P, Richter M. Treatment of severe mandibular fractures using $A O$ reconstruction plates. J Oral Maxillofac Surg. 2003;61(4):458-61. doi: 10.1053/joms.2003.50087

22. Newlands SD, Samudrala S, Katzenmeyer WK. Surgical treatment of gunshot injuries to the mandible. Otolaryngol - Head Neck Surg. 2003;129(3):239-44.

23. Maliska MCDS, Lima Júnior SM, Gil JN. Analysis of 185 maxillofacial fractures in the state of Santa Catarina, Brazil. Braz Oral Res. 2009;23(3):268-74. doi: 10.1590/S180683242009000300008

24. Ellis E, Muniz O, Anand K. Treatment considerations for comminuted mandibular fractures. J Oral Maxillofac Surg. 2003;61(8):861-70. doi: 10.1016/S0278-2391(03)00249-0

25. Vyas A, Mazumdar U, Khan F, Mehra M, Parihar L, Purohit C. A study of mandibular fractures over a 5-year period of time: a retrospective study. Contemp Clin Dent. 2014;5(4):452. doi: 10.4103/0976-237X.142808

26. Miles BA, Potter JK, Ellis E. The efficacy of postoperative antibiotic regimens in the open treatment of mandibular fractures: a prospective randomized trial. J Oral Maxillofac Surg. 2006;64(4):576-82. 10.1016/j.joms.2006.01.003

27. Zallen RD, Curry J. A study of antibiotic usage in compound mandibular fractures. J Oral Surg. 1975;33:431.

28. Wannmacher L, Ferreira MBC. Farmacologia clínica para dentistas. $2^{a}$ ed. Rio de Janeiro: Guanabara Koogan; 1999.

29. Quirke M, Wakai A. Treatment outcome measures for randomized controlled trials of antibiotic treatment for acute bacterial skin and skin structure infections in the emergency department setting. Int J Emerg Med. 2015;8(1):11. doi: 10.1186/s12245015-0060-9

30. Munante-Cardenas JL, Nunes PHF, Passeri LA. Etiology, Treatment, and complications of mandibular fractures. J Craniofac Surg. 2015;26(3):611-5. doi: 10.1097/SCS.0000000000001273

Received on: 22/3/2017

Final version resubmitted on: 11/7/2017

Approved on: 1/8/2017 